\title{
Natural Radioactivity and Associated Dose Rates in Soil Samples of Malnichera Tea Garden in Sylhet District of Bangladesh
}

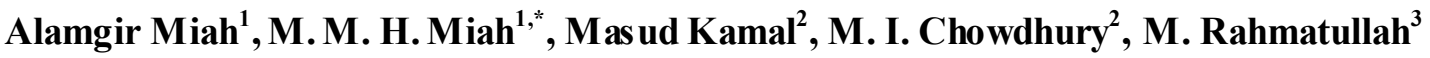 \\ ${ }^{1}$ Department of Phy sics, University of Chittagong, B an gladesh \\ ${ }^{2}$ Radioactivity Testing and Monitoring Laboratory, BAEC, Chittagong, Bangladesh \\ ${ }^{3}$ Department of Community Medicine, Delta Medical College, Mirpur, Dhaka, Bangladesh
}

\begin{abstract}
The activity concentrations of naturally occurring radionuclides ${ }^{226} \mathrm{Ra},{ }^{232} \mathrm{Th}$ and ${ }^{40} \mathrm{~K}$, were measured by using a Broad Energy Ge (BEGe) detector for soil samples collected fro $m$ the Malnichara tea garden in Sylhet district of Bangladesh. The average activity concentrations of ${ }^{226} \mathrm{Ra},{ }^{232} \mathrm{Th}$ and ${ }^{40} \mathrm{~K}$ in soil samples were found to be $55.284 \pm 4.68,125.270 \pm 5.81$ and $497.91 \pm 43.83 \mathrm{Bqkg}^{-1}$, respectively. The results obtained for the corresponding nuclides are slightly higher than the world wide average values of 35,30 , and $400 \mathrm{~Bq} \mathrm{~kg}^{-1}$, respectively. The average outdoor absorbed dose and the annual effective dose rates due to ${ }^{226} \mathrm{Ra},{ }^{232} \mathrm{Th}$ and ${ }^{40} \mathrm{~K}$ were observed to be $124.12 \pm 7.59 \mathrm{n} \mathrm{Gyh}^{-1}$ and $152.22 \pm 9.31 \mu \mathrm{Svy}^{-1}$, respectively; which are above the world average. Whereas, the radium equivalent activity and external hazard indices are less than the world average values.
\end{abstract}

Keywords Activity Concentration, Absorbed Dose, Effective Dose, World Average Values

\section{Introduction}

The natural radioactivity in the environment is the main source of radiation exposure for human body. Natural radionuclide in soil contributes a significant amount of background radiation exposure to the population through inhalation and ingestion. The main contributors of radionuclides are ${ }^{226} \mathrm{Ra},{ }^{232} \mathrm{Th}$ and ${ }^{40} \mathrm{~K}$. Since these radionuclides in soils are not uniformly distributed and vary from region to region ${ }^{(1,2)}$. Therefore the knowledge of their distribution in soil and rock play an important role in radiation protection and measurement ${ }^{(3,4)}$. The radioactivity concentration of these nuclides above permissible level is very harmful to the human body. Therefore, measurements of natural radioactivity in soils and the radiation doses are of great interest to the researchers which have led the nationwide surveys throughout the world ${ }^{(5,6)}$. There have been many surveys to determine the background levels of radionuclides in soils which have been turned out to calculate the absorbed dose in air ${ }^{(4)}$.

The Sylhet district is a traditional tea growing area in Bangladesh. It has about 150 tea gardens, and nearly 300,000 workers are employed in the tea gardens. Bangladesh is earning a lot of fore ign currencies by exporting tea in abroad.

* Corresponding author:

mhmiah85@yahoo.com (M. M. H. Miah)

Published online at http://journal.sapub.org/jnpp

Copyright (C) 2012 Scientific \& Academic Publishing. All Rights Reserved
Tea is a one kind of popular soft drinks. About $70 \%$ of the people in Bangladesh drink tea for refreshment. The Sylhet area is very near to Assam and Tripura of India. Some Uranium deposits were found in those States of India. The aim of the present work is to search the possibility of uranium deposition as ore and health risk assessment associated with Thorium and Potassium in the study area. This work was undertaken to measure the activity concentrations and $\gamma$ - ray absorbed doses of the naturally occurring radionuclides $\left({ }^{238} \mathrm{U},{ }^{232} \mathrm{Th}\right.$ and $\left.{ }^{40} \mathrm{~K}\right)$ in soil samples of Malnichera tea garden in Sylhet. Moreover, another aim of the present work is to create the public awareness about the radiation hazards and the workers those who are working in this tea garden. This study will also be helpful to establish a research base line in this area.

\section{Methods and Materials}

\subsection{Study Area}

Sylhet Division is the northeastern part of Bangladesh, named after its main city, Sy lhet. It is bounded by Meghalaya State of India on the north, Tripura State on the south, Assam State of India on the east and Dhaka division on the west and Chittagong division on the southwest The area around Sylhet is a traditional tea growing area. The Malnichera tea garden is situded in Sylhet sadar district which is nearly $3 \mathrm{Km}$ northern side from the main Sylhet town. A map of Sylhet sadar and the location of this tea garden is shown in Fig. 1. 


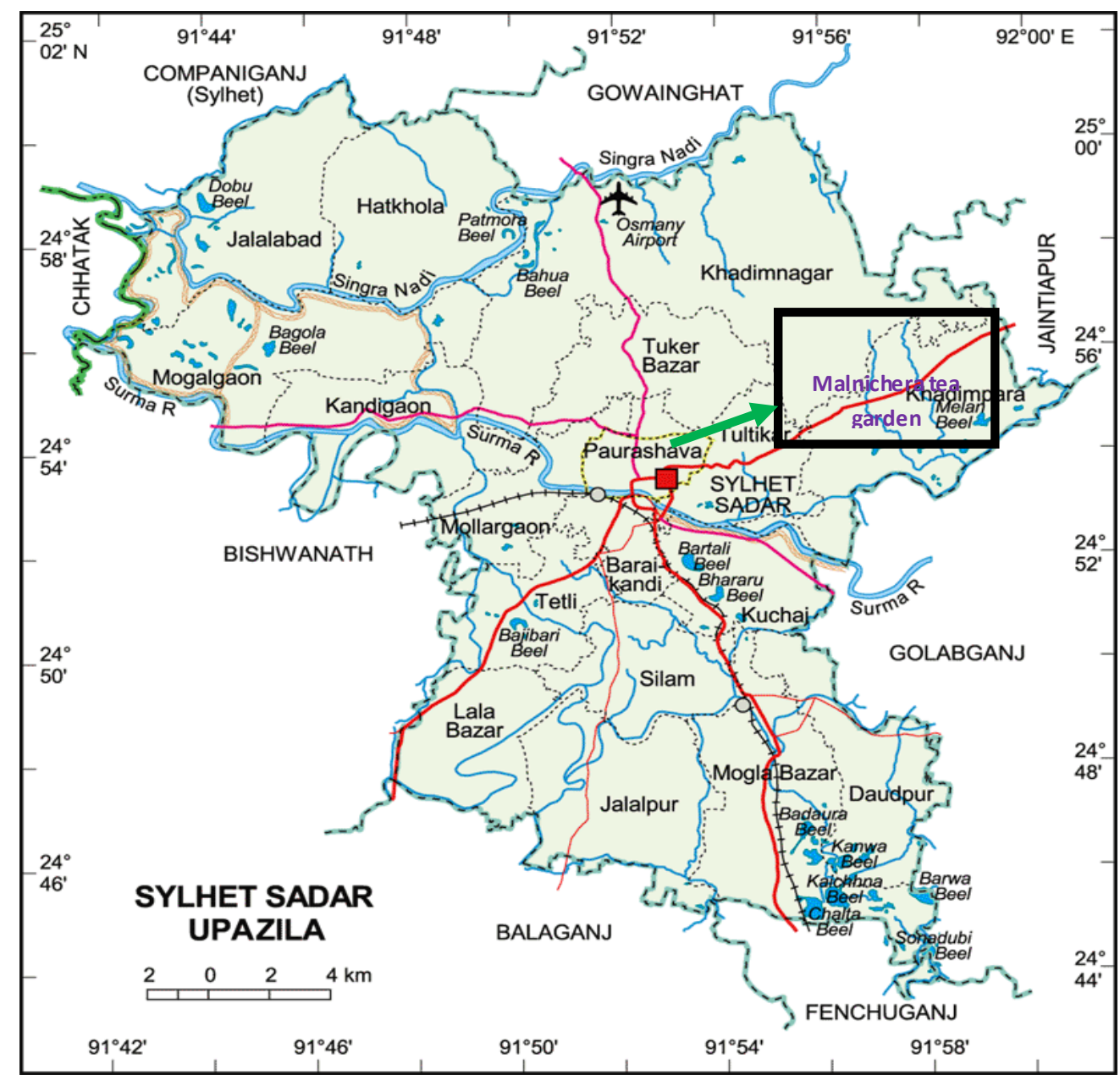

Figure 1. Location map of Malnichera tea garden in Sylhet district of Bangladesh

\subsection{Sampling Loc ations}

A total number of 7 soil samples were collected from the Malnichera tea garden in Sylhet. It is one of the largest tea garden in Bangladesh.All the soil samples were collected during the whole day of 8 March in 2010. The sampling stations are located by the geographical position of Latitude ranged over $24^{\circ} 55.43^{\prime}-25^{\circ} 03.56^{\prime} \mathrm{N}$ and Longitude $91^{\circ} 51.41^{\prime}$ $-92^{\circ} 20.10^{\prime} \mathrm{E}$.

\subsection{Sample Collection and Preparation}

Locations of 7 soil samples were chosen randomly from Malnichara tea garden in Sylhet. Each soil sample was collected from the surface and was marked by the number A1, A2, A3 ....etc.. After collection of samples, they were cleaned and dried into the sun and crushed into fine powder by using a mortar.The homogenized soil samples were then dried in an oven at $60-80^{\circ} \mathrm{C}$ for about 24 hours and then weighted by an electrical balance. All the samples were packed into containers and then sealed tightly with an insulating tape around the opening of the containers for impeding the possibility of moisture contamination of air. In order to maintain radioactive equilibriu m between ${ }^{226} \mathrm{Ra}$ and its daughters, the packed PVC containers were stored for a period of 4 weeks.

\subsection{Gamma-ray Detection System}

In $\gamma$-ray spectrometry, the full energy peak efficiency of a high purity Germanium ( $\mathrm{Hp} \mathrm{Ge}$ ) detector is the number of $\gamma$ rays detected by the detector to the number of photons emitted by the source for a specific energy, which is defined as ${ }^{(4)}$

$$
\varepsilon(E)=\frac{n(E)}{A \times I_{\gamma}}
$$

where, $n(E)$ is the net count rate of the photo peak for the corresponding energy $\mathrm{E}, \mathrm{A}$ is the present activities of the standard reference source wh ich were calcu lated by using the well known decay law: $\mathrm{A}=\mathrm{A}_{0} \mathrm{e}_{-}{ }^{\lambda \mathrm{t}}$. and $\mathrm{I}_{\gamma}$ is the Intensity of the gamma energy. For the determination of efficiency of the detector (HpGe), the contributions for the coincidence summing effect and the angular correlations due to the cascading gamma-rays were taken into account followed by the literatures ${ }^{(7,8)}$. In the present study, the International Atomic Energy Agency (IA EA) reference samp les were used for the calibration of detector efficiencies. The IAEA reference samples are: RGU-1, Uranium is in silica matrix, RGTh-1: Thorium is in silica matrix and RGK-1: potassium sulphate. The standard reference source has the same diameter as the soil samples of known concentrations of ${ }^{238} \mathrm{U}$, ${ }^{232} \mathrm{Th}$ and ${ }^{40} \mathrm{~K}$ radionuclides supplied by the Canada Centre 
for Mineral and Energy Technology (CAMET) under a contract with the IAEA

\subsection{Activity Concentrations of Soil Samples}

The radioactivity of each sample was measured using the calibrated high purity Germanium (HpGe) Detector of energy resolution of $2.0 \mathrm{KeV}$ at $1.33 \mathrm{MeV}$ of ${ }^{60} \mathrm{Co}$. for a period of $10,000 \mathrm{~s}$. Keeping the samples one by one on the top of the detector and counted for a period of $10,000 \mathrm{~s}$. The activity concentration (A) of each radionuclide in the sample was determined by using the net count rates $\left(\mathrm{N}_{\mathrm{c}}\right)$ after subtracting the background counts from the gross counts for the same counting time under the selected photo peaks, weight of the sample, the photopeak efficiency and the gamma intensity at a specific energy as:

$$
\mathrm{A}=\left(\mathrm{N}_{\mathrm{c}} \times 1000\right) /\left(\varepsilon \times \mathrm{I}_{\gamma} \times \mathrm{W}\right)
$$

Where, $\mathrm{A}=$ Activity concentration of the sample in $\mathrm{Bq} / \mathrm{Kg}$

Net count rate, $\mathrm{N}_{\mathrm{c}}=$ Gross counts per second from the samples - background counts per second

$\varepsilon=$ Efficiency of the detector for the specific energy.

$\mathrm{I}_{\gamma}=$ Intensity of the gamma ray.

$\mathrm{W}=$ Sa mple weight in $\mathrm{gm}$.

For the analysis of peak areas of gamma spectra, a Co mputer software programming (GENE 2000) was used.

\subsection{Abs or bed Dose Rates}

The external outdoor absorbed gamma dose rates due to terrestrial $\gamma$-rays from the nuclides ${ }^{226} \mathrm{Ra},{ }^{232} \mathrm{Th}$ and ${ }^{40} \mathrm{~K}$ at 1 $\mathrm{m}$ above the ground level was calculated as (UNSCEAR 2000) ${ }^{(9)}$

$$
D=\left(0.0414 C_{\mathrm{K}}+0.623 C_{\mathrm{Th}}+0.461 \mathrm{C}_{\mathrm{Ra}}\right) \mathrm{nGy} \mathrm{h}^{-1}
$$

Where, $C_{\mathrm{K}}, C_{\mathrm{Th}}, \mathrm{C}_{\mathrm{Ra}}$, are the average activity concentrations of ${ }^{40} \mathrm{~K},{ }^{232} \mathrm{Th}$ and ${ }^{226} \mathrm{Ra}$. About $98 \%$ of the external $\gamma$ dose rate from ${ }^{238} \mathrm{U}$ series is delivered by the ${ }^{226} \mathrm{Ra}$ sub series. So disequilibrium, between ${ }^{226} \mathrm{Ra}$ and ${ }^{238} \mathrm{U}$ will not affect the results of dose calculations from the measurement of ${ }^{226} \mathrm{Ra}$.

\subsection{Annual Effective Dose Rates}

The absorbed dose rate was converted into annual effective dose equivalent by using a conversion factor of 0.7 $\mathrm{SvGy}^{-1}$ recommended by the UNSCEAR ${ }^{(9)}$ and 0.2 for the outdoor occupancy factor by considering that the people on the average, spent $\sim 20 \%$ of their time in outdoors ${ }^{(8)}$. The Effective dose due to natural activity in the soil was calculated by:

$$
\begin{aligned}
\text { Effective dose, } \mathrm{E} & =\text { Dose rate } \\
\mathrm{D}\left(\mathrm{n} \mathrm{Gyh}^{-1}\right) \times 8760\left(\mathrm{hy}^{-1}\right) & \times 0.2 \times 0.7 \mathrm{~Sv} \mathrm{~Gy}^{-1} \times 10^{3}
\end{aligned}
$$

\subsection{Radium Equi valent Activity}

Radionuclides of ${ }^{226} \mathrm{Ra},{ }^{232} \mathrm{Th}$ and ${ }^{40} \mathrm{~K}$ are not homogeneously distributed in soil. The inhomogeneous distribution from these naturally occurring radionuclides is due to disequilibrium between ${ }^{226} \mathrm{Ra}$ and its decay products. For uniformity in exposure estimates, the radionuclide concentrations have been defined in terms of radium equivalent activity $\left(\mathrm{Ra}_{\mathrm{eq}}\right)$ in $\mathrm{Bq} \mathrm{kg}{ }^{-1}$. This allows comparison of the specific activity of materials containing different amounts of ${ }^{226} \mathrm{Ra},{ }^{232} \mathrm{Th}$ and ${ }^{40} \mathrm{~K}$ according to Beretka and Mathew ${ }^{(10)}$ as follows.

$$
\mathrm{Ra}_{\mathrm{eq}}=\mathrm{C}_{\mathrm{Ra}}+1.43 C_{\mathrm{Th}}+0.077 C_{\mathrm{K}}
$$

Where, $\mathrm{C}_{\mathrm{Ra}}, C_{\mathrm{Th}}$ and $C_{\mathrm{K}}$ are the activity concentrations of ${ }^{226} \mathrm{Ra},{ }^{232} \mathrm{Th}$ and ${ }^{40} \mathrm{~K}$ in $\mathrm{Bq}{ }^{\mathrm{kg}-1}$, respectively.

\subsection{External Hazard Index}

The external hazard index $\left(\mathrm{H}_{\mathrm{ex}}\right)$ is the indoor radiation dose rate due to the external exposure to gamma radiation in construction materials of dwellings which was calculated by ${ }^{(11):}$

$$
H_{e x}=\frac{C_{R a}}{370}+\frac{C_{T h}}{259}+\frac{C_{K}}{4810}
$$

Where, $C_{\mathrm{Ra}}, \mathrm{C}_{\mathrm{Th}}$ and $\mathrm{C}_{\mathrm{k}}$ are the specific activities of ${ }^{226} \mathrm{Ra}$, ${ }^{232} \mathrm{Th}$ and ${ }^{40} \mathrm{~K}$ in Bq.kg-1, respectively. This index value must be less than unity to the radiation hazard insignificant i.e; the area is safe to the human for living.

\subsection{The Ratio of ${ }^{226} R /{ }^{228} R$}

The ratio of ${ }^{226} \mathrm{R} /{ }^{228} \mathrm{R}$ concentration activities is less than 1 because the concentration activity of ${ }^{226} \mathrm{Ra}$ in soil is less than the concentration of ${ }^{228} \mathrm{Ra}$. In other word, the concentration of uranium in soil is less than thorium, since uranium and thorium are the parents of ${ }^{226} \mathrm{Ra}$ and ${ }^{228} \mathrm{Ra}$, respectively. The range of this ratio is obtained 0.356- 0.586 .

\section{Results and Discussion}

In the present study of soil samples at Malnichara tea garden in Sylhet district of Bangladesh, the results can be summarized as:

i). Activity concentrations, and ii). Radio logical indices.

\subsection{Activity Concentrations in Soil Samples}

Activity concentrations for nuclides ${ }^{226} \mathrm{Ra},{ }^{232} \mathrm{Th},{ }^{40} \mathrm{~K}$ and ${ }^{137} \mathrm{Cs}$ in Malnichara tea garden soil samples were determined by equation (2) and the results for the same have been shown in Table 1 with the uncertainty of $1 \sigma$ level. Here, the table shows that the highest value is found for sample 7A. The highest value of the nuclide may vary fromp lace to place and this variation may be due to the chemical changes of the constituent elements of soils. Moreover, it is also possible due to the excess use of agricultural fertilizers and pesticides. All the associated errors were added in quadrature in order to obtain the total uncertainty. The results for the nuclides $\left({ }^{226} \mathrm{Ra},{ }^{232} \mathrm{Th}\right.$ and $\left.{ }^{40} \mathrm{~K}\right)$ are also shown independently through Fig. $2,3 \& 4$, respectively.

\section{2. ${ }^{226}$ Ra Acti vity}

In soil samples, the activity concentrations of ${ }^{226} \mathrm{Ra}$ were found in the range of $23.91 \pm 4.19-143.70 \pm 7.38 \mathrm{~Bq} / \mathrm{kg}$, with 
an average value of $55.25 \pm 4.68 \mathrm{~Bq} / \mathrm{kg}$. Th is result is higher than the worldwide average value of $35 \mathrm{~Bq} / \mathrm{kg}$ (shown by the dotted line) for the same radionuclide in soils reported by UNSCEAR $^{(9)}$

\section{3. ${ }^{232}$ Th Activity}

The activity concentration of ${ }^{232} \mathrm{~T}$ is found in the range of $53.25 \pm 4.80-369.60 \pm 10.52 \mathrm{~Bq} / \mathrm{kg}$ with mean value $125.27 \pm$ $5.81 \mathrm{~Bq} / \mathrm{kg}$. This result is also higher than the world average of $30 \mathrm{~Bq} / \mathrm{kg}^{(9)}$ (shown by the dotted line).

Table 1. Activity concentrations (in $\mathrm{Bq} / \mathrm{kg}$ ) in soil samples

\begin{tabular}{|c|c|c|c|c|}
\hline Sample ID & ${ }^{226} \mathrm{Ra} \mathrm{Bq} / \mathrm{kg}$ & ${ }^{232} \mathrm{Th} \mathrm{Bq} / \mathrm{kg}$ & ${ }^{40} \mathrm{~K} \mathrm{~Bq} / \mathrm{kg}$ & ${ }^{137} \mathrm{Cs} \mathrm{Bq} / \mathrm{kg}$ \\
\hline 1A & $58.98 \pm 4.16$ & $100.71 \pm 4.39$ & $544.43 \pm 39.72$ & $\mathrm{ND}^{*}$ \\
\hline 2A & $23.91 \pm 4.20$ & $58.76 \pm 4.89$ & $593.03 \pm 51.53$ & $17.32 \pm 1.17$ \\
\hline 3A & $45.07 \pm 4.47$ & $126.56 \pm 6.25$ & $471.61 \pm 42.65$ & $\mathrm{ND}^{*}$ \\
\hline 4A & $29.24 \pm 4.19$ & $53.25 \pm 4.81$ & $576.35 \pm 48.22$ & ND $^{*}$ \\
\hline 5A & $48.09 \pm 4.79$ & $99.14 \pm 5.64$ & $369.35 \pm 43.56$ & ND $^{*}$ \\
\hline 6A & $37.73 \pm 3.34$ & $68.87 \pm 3.49$ & $442.39 \pm 34.57$ & ND $^{*}$ \\
\hline 7A & $143.70 \pm 7.38$ & $369.61 \pm 10.52$ & $461.23 \pm 46.54$ & ND $^{*}$ \\
\hline Average & $55.25 \pm 4.68$ & $125.27 \pm 5.81$ & $497.91 \pm 43.83$ & $17.32 \pm 1.17$ \\
\hline Range & $23.91 \pm 4.19-$ & $53.25 \pm 4.80-$ & $369.35 \pm 43.56-$ & $17.32 \pm 1.17$ \\
\hline
\end{tabular}

$\mathrm{ND}^{*}=$ Not detected

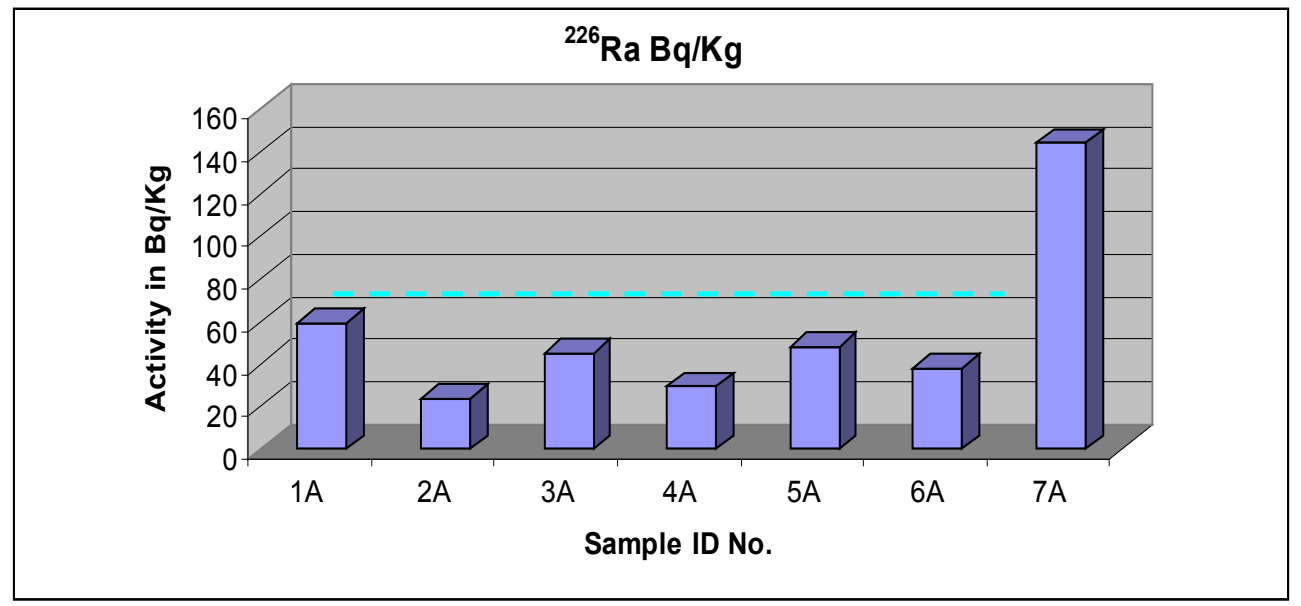

Figure 2. Distribution of ${ }^{226} \mathrm{Ra}$ in soil samples

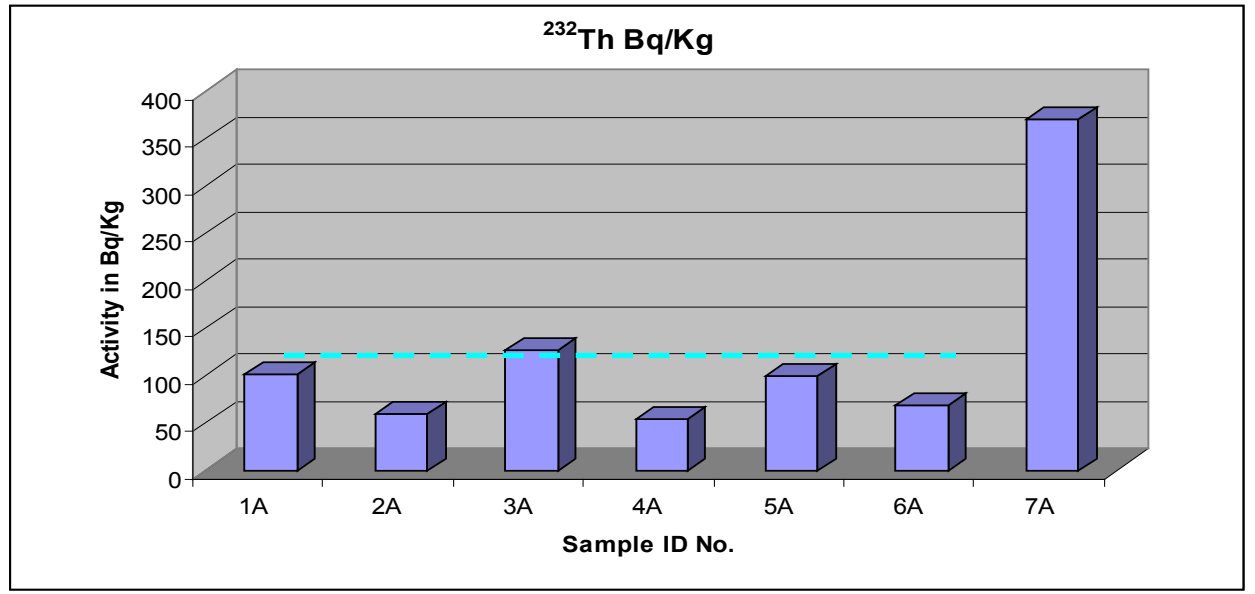

Figure 3. Distribution of ${ }^{232} \mathrm{Th}$ in soil samples 


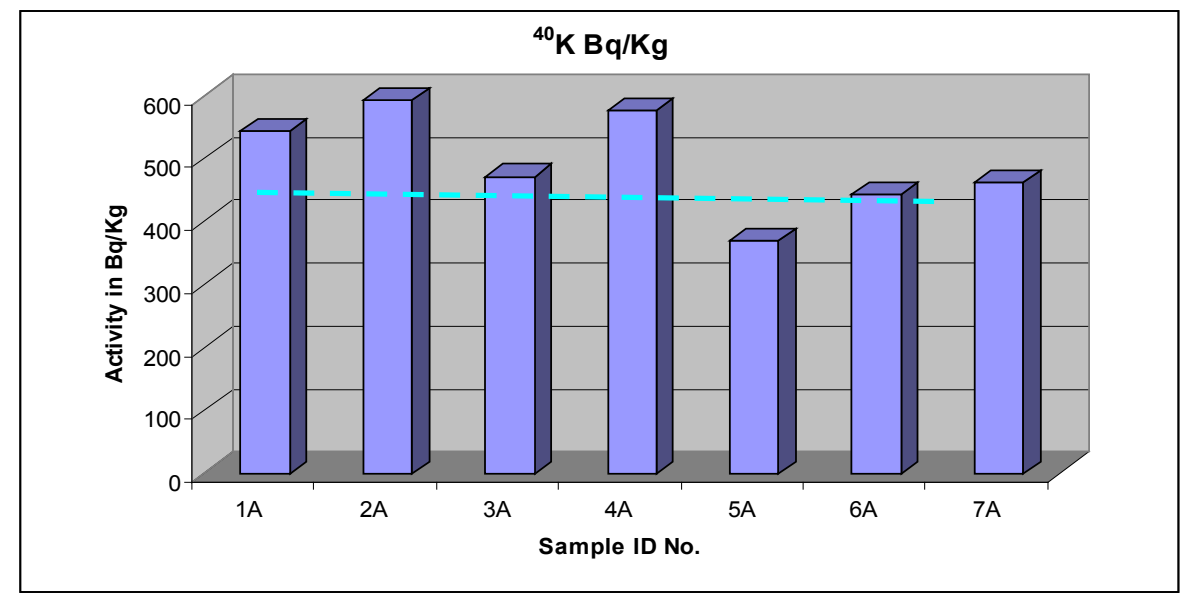

Figure 4. Distribution of ${ }^{40} \mathrm{~K}$ in soil samples

Table 2. The ratio ${ }^{226} \mathrm{Ra}{ }^{228} \mathrm{Ra}$, Radium equivalent act ivity, Absorbed dose rate, Effect ive dose rate and External hazard index

\begin{tabular}{|c|c|c|c|c|c|}
\hline Sample ID & ${ }^{226} \mathrm{Ra}^{22} \mathrm{Ra}$ & $\begin{array}{c}\mathrm{Ra}_{\mathrm{eq}} \text { activity } \\
(\mathrm{Bq} / \mathrm{kg})\end{array}$ & $\begin{array}{c}\text { Absorved dose rate, } \mathrm{D} \\
(\mathrm{nGy} / \mathrm{h})\end{array}$ & $\begin{array}{c}\text { Effect ive dose rate, } \\
\mathrm{E}(\mu \mathrm{Sv} / \mathrm{y})\end{array}$ & $\begin{array}{c}\text { External hazard } \\
\text { index }\left(\mathrm{H}_{\mathrm{ex}}\right)\end{array}$ \\
\hline 1A & 0.586 & $241.10 \pm 14.19$ & $112.47 \pm 6.72$ & $137.93 \pm 7.72$ & 0.661 \\
\hline 2A & 0.406 & $149.45 \pm 14.79$ & $72.18 \pm 7.11$ & $88.52 \pm 8.72$ & 0.415 \\
\hline 3A & 0.356 & $259.06 \pm 16.39$ & $119.15 \pm 7.72$ & $146.12 \pm 9.46$ & 0.708 \\
\hline 4A & 0.549 & $145.74 \pm 14.68$ & $70.52 \pm 7.03$ & $86.48 \pm 8.63$ & 0.404 \\
\hline 5A & 0.485 & $215.71 \pm 15.91$ & $100.34 \pm 7.53$ & $121.69 \pm 9.23$ & 0.589 \\
\hline 6A & 0.547 & $167.18 \pm 10.75$ & $78.61 \pm 5.15$ & $96.41 \pm 6.31$ & 0.460 \\
\hline 7A & 0.388 & $704.53 \pm 25.68$ & $315.61 \pm 11.88$ & $387.06 \pm 14.57$ & 0.968 \\
\hline Average & 0.441 & $269.24 \pm 16.06$ & $124.12 \pm 7.59$ & $152.23 \pm 9.31$ & 0.601 \\
\hline Range & $0.356-0.586$ & $145.74 \pm 14.68-704$ & $70.52 \pm 7.03-315.60 \pm 1$ & $86.48 \pm 8.62-387.06 \pm$ & $0.404-0.968$ \\
\hline
\end{tabular}

\section{4. ${ }^{40}$ KActivity}

The activity of ${ }^{40} \mathbf{K}$ is found in the range $369.35 \pm 43.56-$ $593.02 \pm 51.52 \mathrm{~Bq} / \mathrm{kg}$ with an average value of $497.91 \pm 43.83$ $\mathrm{Bq} / \mathrm{kg}$. This result is also slightly higher than the worldwide average of $400 \mathrm{~Bq} / \mathrm{kg}$ (dotted line) for the same kind of nuclide ${ }^{(5)}$

\section{5. ${ }^{137}$ Cs Activity}

The concentration of ${ }^{\mathbf{1 3 7}} \mathbf{C s}$ is found to be $17.32 \pm 1.17$ $\mathrm{Bq} / \mathrm{Kg}$ in the soil sample 2A.In other soil samples, the concentrations of ${ }^{\mathbf{1 3 7}} \mathrm{Cs}$ are not detectable.

\subsection{Radiological Indices}

In order to assess the health effects, the radiation hazards such as absorbed dose rate (D), effective dose rates (E), radium equivalent activity $\left(\mathrm{Ra}_{\mathrm{eq}}\right)$, and external hazard index $\left(\mathrm{H}_{\mathrm{ex}}\right)$ have been calculated from the activity of nuclides ${ }^{226} \mathrm{Ra}$, ${ }^{232} \mathrm{Th},{ }^{40} \mathrm{~K}$ using the equations (3), (4), (5) and (6), respectively and the values have shown in Table 2 .

From Table 2, it shows that the radium equivalents activity $\left(\mathrm{Ra}_{\mathrm{eq}}\right)$ is found in the range of $145.74 \pm 14.68-704.53 \pm$ $25.68 \mathrm{~Bq} / \mathrm{kg}$, an average value of $269.24 \pm 16.06$. The average value of the radium equivalent is less than the safe limits as recommended by the organization for Economic cooperation and development $(E C D)^{(6)}$. Any $R_{\text {aeq }}$ Concentration value that exceeds $370 \mathrm{~Bq} / \mathrm{kg}$ may pose radiation hazards

The outdoor air absorbed dose rate due to terrestrial gamma rays at $1 \mathrm{~m}$ above the ground were calculated for ${ }^{226} \mathrm{Ra},{ }^{332} \mathrm{Th}$ and ${ }^{40} \mathrm{~K}$ and the range is $70.52 \pm 7.03-$ $315.60 \pm 11.88 \mathrm{nGyh}^{-1}$ with an average of $124.12 \pm 7.59$ $\mathrm{nGyh}^{-1}$ which is higher than the world average value of 60 nGyh- ${ }^{1(5)}$.

The annual effective dose rate equivalent is calculated using a conversion factor of $07 \mathrm{SvGy}^{-1}$ to convert the absorbed dose rate to the effective dose equivalent and 0.2 for the outdoor occupancy factor. The annual effective dose rates are found in the range of $86.48 \pm 8.62-387.06 \pm 14.57$ $\mu \mathrm{Svy}^{-1}$ with an average value is $152.23 \pm 9.31 \mu \mathrm{Svy}^{-1}$, which is also higher than the world average of $80 \mu \mathrm{Svy}^{-1}$. Indoor dose rates were not evaluated because the essential data on the average build-up of radon gas in the indoor atmosphere were not available.

The mean value of external radiation hazard index is 0.60 which is less than 1 , and confirms that it is safe to carry out the activities for the human in that area. The ratio of ${ }^{226} \mathrm{R} /$ ${ }^{228} \mathrm{R}$ concentration activities is less than 1 because the 
concentration activity of ${ }^{226} \mathrm{Ra}$ in soil is less than the concentration of ${ }^{228} \mathrm{Ra}$. In other words, the concentration of uranium in soil is less than thorium, since uranium and thorium are the parents of ${ }^{226} \mathrm{Ra}$ and ${ }^{228} \mathrm{Ra}$, respectively. The range of this ratio is obtained $0.356-0.586$.

\section{Conclusions}

In the present study, the results indicate that the natural radioactivity concentration of ${ }^{226} \mathrm{Ra}$ is relatively lower than that of ${ }^{232} \mathrm{Th}$ and ${ }^{40} \mathrm{~K}$ at the vicinity of Malnichera tea garden in Sylhet district of Bangladesh. The values of mean absorbed dose rate, annual effective dose rate and the radium equivalent activity were higher than the global average values; whereas the external hazard index is less than unity which indicates that the area is no threat of exposure for the population..

Previously, no works on the tea garden for radioactivity measurement of the soil samples in Sylhet division was carried out. Therefore, this work can be used as a baseline data for further research work.

\section{REFERENCES}

[1] Bozkurt, A., Yorulmaz, N., Kam, E., Karahan, G. and Osmanlioglu, A.E. Assessment of environmental radioactivity for Sanliurfa region of southeastern Turkey. Rodiat, Meas. doi: 10.1016/j.radmeas.2007.05.052.

[2] Tzortzis M, Svoukis E. and Tsertos H. (2001): A comprehensive study of natural gamma radioactivity levels and associated dose rates from surface soils in Cyprus, J. Radiant Prot Dosim. 109, 217-224.
[3] Rani, A. and Singh, S. Natural radioactivity levels in soil samples from some areas of Himachal Pradesh India using $\gamma$-ray spectrometry. Atoms. Environ.39, 6306-1634(2005).

[4] Kannan, V., Rajan, M.P., Lyengar, M.A. and Ramesh, R. Distribution of natural and anthropogenic rodionuelides in soil and beachsand Samples of Kalpakkam (India). Appl. Rodiat. Isot.57,109-119 (2002)

[5] Karahan, G. and Bayulken, A. Assessment of gamma dose rates around Istanbul (Turkey). J. Environ. Rodioact. 47, 213-211 (2000). (5)

[6] Degerlier, M., Karahan, G.and Ozger,. Radioactivity concentrations and dose assessment for soil samples, around Adana, Turkey. J. Environ. Radioact. 99, 1018-1025 (2008).(6)

[7] H. Fraunfelder and R.M. Steffen (1968): Alpha, Beta and Gamma-ray Spectroscopy, ed. By K. Siegbahan), Vol. 2, pp. 997-1198.(7)

[8] K. Debertin and R.G. Helmer . Gammand X-ray speetrometry detectiors. North Holland, 1988. (8)

[9] United Nations Scientific Committee of the effect of Atomic Radiation (UNSCEAR) 2000: Sources and Effects of Ionizing Radiation. Report on General assembly, United Nations, New York. (9)

[10] Beretka, J. and Mathew, P.J. Natural radioactivity of Australian buildings, materials, industrial wastes and byproducts. Health Phys, 48,87-95 (1985. (10)

[11] Lu, X.and Xiolan, Z. (2006): Measurement of natural radioactivity in sand samples collected from the Booje Weihe sand park, China. Environ. Geol. 50, 977-988. 